\title{
The Effects of Socioeconomic Characteristics of Students on Their Academic Achievement in Higher Education
}

\author{
Ekber TOMUL ${ }^{1, *}$, Gökhan POLAT ${ }^{2}$ \\ ${ }^{1}$ Faculty of Education, Department of Elementary Education, Mehmet Akif Ersoy University, Burdur, Turkey \\ ${ }^{2}$ Gökhan POLAT School of Foreign Languages, University of Suleyman Demirel, Isparta, Turkey \\ *Corresponding author: etomul@mehmetakif.edu.tr
}

Received November 04, 2013; Revised December 07, 2013; Accepted December 12, 2013

\begin{abstract}
The aim of this study is to determine the effect of the socioeconomic status of higher education students on their academic achievement and the relationship between these determinants. The study is conducted on the 691 undergraduate senior students being trained at the University of Suleyman Demirel who were chosen by their Weighted Quantitative Composite scores in the Student Selection Examination. In the study, student' Student Selection Examination Weighted Quantitative Composite scores which were taken into account when they were accepted for their departments and their average grade of the academic scores until their final year are used as the dependent variables. Average grade point of the academic scores is the overall mean scores that the students have until the beginning of the final year in their departments. As for the independent variables, parents' educational status, family income, the settlement where the family lives, the status of the fathers' workplace, number of siblings and the educational background of the student before the Student Selection Examination are taken into consideration in the study. Obtained data has been analyzed by using correlation, regression and two-way variable analysis methods. The results of the study indicate that the high school type from which the students have been graduated can be said as an essential predicator for the students' academic achievement. The variables related to the family are not strong predicators. That education institutions prior to the higher education also accept students with a national exam has increased the homogeneity of the higher education student profile.
\end{abstract}

Keywords: academic achievement, academic outcomes, educational policy, socio economic status, sociology of education, higher education

Cite This Article: Ekber TOMUL, and Gökhan POLAT, "The Effects of Socioeconomic Characteristics of Students on Their Academic Achievement in Higher Education.” American Journal of Educational Research 1, no. 10 (2013): 449-455. doi: 10.12691/education-1-10-7.

\section{Introduction}

Higher education becomes an important political issue within the knowledge-based economy. [1] For the individual, higher education is an important determiner for personal career and economic success and for the society it forms the basis of society's economic performance. [2] Since higher education ensures high income and better job opportunities, it is directly related to individuals' success in business. From the social point of view, it has an important role in a community's attainment of such socially determined aims as high quality workforce, equal opportunities, social unity and development of civil awareness. From the economic point of view, developed workforce encourages renovation and increases a country's competitive power in the growing global market.

The opportunities that education affords to individuals and societies bring to the foreground the issues of quality and equality of opportunity in higher education. However, the presence of considerable differences in academic achievement as related to poor educational standards in most countries attracted attention to this field [3].
According to the Organization for Economic Cooperation and Development (OECD), academic achievement at school is not only linked with schoolrelated factors but also with the socioeconomic environment in which students are raised. [4] Social scientists have emphasized since the mid-1960s in their research that the socioeconomic conditions of the family is an important factor in students' academic achievement. $[5,6,7,8]$ In the "Equal Opportunity Study" conducted by Coleman et al. in the US, it is stated that the qualitative and quantitative characteristics of the school do not have a significant effect on the success of the student. According to this study, students' academic attainment is determined by the family's socio-economic characteristics and social environmental factors that are outside the school. [9] Ichado indicates that the environment that students come from largely influences their school performance. [10] Rothman suggests that children from low socioeconomic conditioned families do not have a study environment in their homes to have a positive influence on their academic achievement at school. [7] According to Eskicumalı, the reason for failure among lower-class students with low school success rates is the absence of cultural background and lack of friends from the high-class. [11] Eweniyi 
explains that students' low academic achievement has personal and institutional reasons. Personal reasons are related to an individual's intelligence, knowledge and talents while institutional reasons are associated with familial and parental influences, social reasons, schoolrelated reasons, relationships between the student and the instructor, home and living conditions. [3] Croll states that, when compared to others, students with a lot of opportunities achieve better results in some examinations, continue their educations for a longer time, and have a better chance at pursuing higher education [12].

Studies show that the socioeconomic status of the family has an important effect on the student's academic achievement at school. [4,5,8,9,13-19]. According to Kean and Tsai, every action of the family is a determiner that has an effect on the children's educational outcomes. [13] The studies conducted on the relationship between the students' academic achievement and the families' socioeconomic status concentrate on such topics as family income, parents' level of education, family model, location of residence, the language used in the family, ethnic roots, previous level of education, acquired behaviors and talents $[2,4,9,14,16]$.

Heyneman and Loxley suggest that there are differences in the effects of the family's socio-economic characteristics and school on student achievement depending on the degree to which the country is developed. As the level of development of a society increases, the impact of the family's socio-economic characteristics on the student's success increases and the impact of the school decreases. As the society's level of development decreases, the impact of the family's socioeconomic characteristics on student success decreases and the impact of the school increases. [20] The results of the Programme for International Student Assessment (PISA) 2003 support these findings. Among the (OECD countries, one fifth of the variability observed in students can be explained as related to the socioeconomic variables that the students come from, although with large differences in this amount from one country to another. The student socioeconomic status in Germany can account for $23 \%$ of student academic achievement. On the other hand, in Japan, socioeconomic status can only account for $12 \%$ of student academic performance [4,8]. Chiu, studied the effect of the family socioeconomic status on 15 year-old students' academic achievement in science based on data from 41 countries. In this study, it was determined that the socioeconomic status of the family and educational sources (cultural composition of the family, level of education of the parents, educational situation of the siblings) have an important effect on the student academic achievement in science [6].

In addition, the education of parents has an impact on children's school achievement. [4,17,21] Studies emphasize that education level of parents of successful students is higher than education level of the parents of unsuccessful students. [22] Kean and Tsai states that the average period of time that parents participate in education is an important factor in students' academic success. [13] De Broucker and Underwood point out that those parents with high education provide the most conducive environment for their children to study, thus providing the necessary motivation for them to proceed to higher education [23]. Like Harmon and Walker, Chevalier and
Lanot also pointed out that student academic achievement is closely related to family income but that family's education is the most important factor. Moreover, they stated that the educational preferences of the children generally reflect family characteristics [24,25]. Brunello and Checci make a point that family's education is an important and strong element in the determination of student achievement. It was found in the study conducted by The Program for International Student Assessment that those students with high school graduate mothers achieve more success than others Furthermore, those students with university graduate in OECD countries are more advantageous and obtain better results. Those students with mothers who are not university graduates achieve lower results in all of the OECD countries. In some countries, mother to be university graduates make a very important impact on student success [26].

Blanden and Gregg point out that family income has an effect on children's educational gains. The per capita expenditure in the family is an indicator of the continuous income of the family. The amount of per capita expenditure has a positive effect on school achievement. For this reason, the increases in the continuous income of the family facilitate the increase in literacy and rise of school achievement in both boys and girls at all stages of education. According to the PISA study, the economic status of a student's family has an impact on academic success. The results of the PISA study show that this relationship is positive, although complicated. It can be said that those students with families who are financially in a good conditions are more successful compared to those who are not. The students with more affluent families obtain better grades compared to those with poorer families. As a result of the social policies embraced by some (OECD countries, financial state does not pose a barrier against success. Students with families in the worst financial conditions display the highest success in Finland and Japan. [27] Blanden and Gregg obtained findings that support the results of the PISA report in a study they conducted in England. [27] Moreover, according to the results of an international comparative study, Chiu stated that there is a strong relationship between family income and science academic achievement depending on the income distribution in the country. [6] Chevalier and Lanot stated based on the results of their study that the academic achievement of students with families of poor a financial state is continually falling, but that there is no clear result to show that this income has an effect on children's educational outcomes [25].

Family income is one of the important factors that determine to some extent the duration that the child participates in education. One study shows that the students attending the most successful 5 universities in Taiwan are from the richest and the most well-educated families. [28] Crosnoe et al. state that children from families who lack financial sources are less likely to graduate from high school or continue to university [29].

Such demographic factors as number of siblings or sibling birth order in the family also have an effect on student achievement. When the birth order of the child among other siblings is considered, young children in the family stand a higher chance to participate in education in developing countries because older children help their parents in working in the house or in the field, or 
contribute to the home economy. The number of children also has an important role. In western societies and some developing countries, there is a negative relationship with this condition and the chance of participating in education because the existing sources at hand have to be shared among children. For this reason, families with a lot of siblings may not send each of their children to school [30].

The geographical factors of the location of family residence also play a role in families giving their children a chance to participate in education. In general, the ration of children participating in education can be seen to be higher in urbanized regions of the countries. The degree that a region is modernized and the regional status of job opportunities make an impact on families giving their children a chance to receive education [30].

Research results show that student academic achievement can be predicted based on the socioeconomic variables that exist in students' lives. Field studies indicate that the impact of socioeconomic factors on academic achievement may change as related to educational stage, social policies practiced in the country, developmental conditions of the country and time. [4] It is considered that determining those family variables that affect students' academic achievement at the higher education level in Turkey may provide data for the micro and macro level policies to be developed in order to alleviate inequalities in education and increase quality. In this respect, it will be significant to seek answers to the question: if the academic achievement of higher education students is to be predicted using their economic, social and cultural characteristics, how much the existing variability can be explained by these characteristics? This study aims to determine how the socioeconomic characteristics of students at higher education are related to and have an effect on their academic achievement.

\section{Methodology}

The universe of this study comprises senior students of departments which admit students based on the Weighted Quantitative Composite scores of the Student Selection Examination (SSE) at Süleyman Demirel University (SDU), Turkey. Higher education institutions in Turkey admit students every year based on the scores from the Student Selection and Placement System (SSPS) administered by Student Selection and Placement Center (SSPC). [29] As a result of the Student Selection Exam, students' Weighted Verbal Composite, Weighted Quantitative Composite and V-Q Equally Weighted Composite score values are calculated. University departments admit students based on the determined score type as related to the educational branch. According to the SSPC data, the score values of the students who enroll in SDÜ departments which base their admission on Weighted Quantitative Composite scores are average and below average, when compared to other universities in Turkey. At SDÜ, the Faculties of Engineering and Architecture (Departments of Civil Engineering, Mechanical Engineering, Textile Engineering, Food Engineering, Electronics Engineering and Communications, Geology Engineering, Geophysics, Environmental Engineering, Mining Engineering and Department of Architecture), Faculty of Forestry, Faculty of Agriculture, Faculty of Dentistry, Faculty of Medicine, Faculty of Arts and Sciences (Physics, Chemistry, Biology, Mathematics Departments) Isparta Higher School of Health (Physical Therapy and Rehabilitation Nursing and Midwifery Departments) admit students with Weighted Quantitative Composite scores. There are a total of 845 senior students in these departments.

As the dependent variable of the study, the SSE Weighted Quantitative Composite (SSEWQC) scores and grade point average of the academic scores (GPA) were taken. GPA is the general average score that the students obtained through the semesters up to their senior year. Five indicator variables were taken as the socioeconomic characteristics of the family in the educational sociology field as the most frequently cited in the conceptual and empirical literature. [9] These are the parents' level of education, family income, family location, father's occupation and number of siblings. In addition, whether the students attended extra courses for educational support to prepare them for the university examination before they entered their departments and if so, the duration of attendance and the paid amount for the support were also included as variables.

The data of the study were collected through a questionnaire which contained items regarding student socioeconomic, demographic, academic achievement status (SSEWQC and GPA). [32] The senior students were asked to write in an open style their GPA grade that they obtained at the end of the 2006-2007 academic year over 100. However, the scores of those students which were stated over the scale of 4 were transformed to scores over 100 based on the SDU score transformation table. The entry scores of the students were checked according to Student Selection and Placement Center lowest and highest values of student admittance to departments. The entry score values which did not fall into the Student Selection and Placement Center value range were excluded. The data collected from 691 were analyzed and interpreted.

In the coding process of the collected data the characteristics of the variables were considered. Monthly income of the families was asked through an open ended question and the stated values were added to the data. The level of education of the parents was indicated as: nongraduate $=1$, primary school graduate $=5$, graduate of secondary school or equivalent schools $=8$, graduate of high school or equivalent schools $=11$, two year undergraduate $=13$, undergraduate $=15$, post graduate $=$ 18 and doctoral $=21$ years. The location of the family was entered as: (1) village, (2) town center and (3) city center. The high school that students graduated from was entered as: (1) vocational high school, (2) General and language high school, (3) Anatolian high school, and (4) Science high school. The status of the father's occupation was entered as: (1) freelance, (2) private, and (3) state institution.

The relationship between the dependent and independent variables was determined using the correlation analysis technique at the first stage. Based on the correlation coefficient obtained as a result of the correlation analyses, the multivariate regression analysis technique was employed to test the common and relative effects of the independent variables on the dependent variables. The degree of significance of the differences 
between students' SSEWQC and GPAs as related to their high school and its effects were tested through one way analysis of variance test. Analysis of variance is the most useful analysis technique which can be used to test the effect of a categorical independent variable on a dependent variable. The level of significance of the relationship between the variables was evaluated and interpreted at the significance level of $\mathrm{p}<.05$.

\section{Results}

The correlation analysis regarding the relationship between socioeconomic variables and the SSEWQC scores and GPAs are presented in Table 1. According to this table, there is a significant positive relationship between the SSEWQC scores and the high school completed, father's education, mother's education, father's occupation, and family income. There is a significant positive relationship between the students' GPAs and high school completed and the father's occupation. There is no significant relationship between the other variables.

According to Table 1, the educational support, duration of educational support, and the fee paid for the educational support do not have a significant relationship with the student SSE scores and GPAs. $90.7 \%$ of the students attended a private institution or private courses to prepare them for the SSE examination. Students stated that on average they attended a private institution or a private course to prepare them for the SSE exam. An average of
1600 dollars (2088 YTL) was paid per student to these courses.

Table 1. Results of the correlation analysis showing the correlation coefficients between socioeconomic variables and SSEWQC scores and GPA

\begin{tabular}{ccccc}
\hline & & $\begin{array}{c}\text { Pearson } \\
\text { Correlation }\end{array}$ & $\begin{array}{c}\text { Sig. } \\
(2 \text {-tail) }\end{array}$ & N \\
\hline \multirow{2}{*}{ Type of high school } & SSEWQC & $.360\left(^{* *}\right)$ & 0.000 & 691 \\
& GPA & $.118\left(^{* *}\right)$ & 0.002 & 691 \\
\hline \multirow{2}{*}{ Educational support } & SSEWQC & 0.065 & 0.089 & 689 \\
& GPA & 0.010 & 0.790 & 689 \\
\hline Duration of educational & SSEWQC & 0.017 & 0.683 & 599 \\
support & GPA & 0.013 & 0.755 & 599 \\
\hline Fee paid for educational & SSEWQC & -0.068 & 0.132 & 485 \\
support & GPA & -0.006 & 0.892 & 485 \\
\hline \multirow{2}{*}{ Family location } & SSEWQC & 0.030 & 0.429 & 691 \\
& GPA & -0.074 & 0.052 & 691 \\
\hline \multirow{2}{*}{ Father's education } & SSEWQC & $.146\left(^{* *}\right)$ & 0.000 & 691 \\
& GPA & -0.038 & 0.314 & 691 \\
\hline \multirow{2}{*}{ Mother's education } & SSEWQC & $.130\left(^{* *}\right)$ & 0.001 & 689 \\
& GPA & -0.044 & 0.252 & 689 \\
\hline \multirow{2}{*}{ Number of siblings } & SSEWQC & -0.002 & 0.948 & 691 \\
& GPA & -0.039 & 0.307 & 691 \\
\hline \multirow{2}{*}{ Father's occupation } & SSEWQC & $.205(* *)$ & 0.000 & 394 \\
& GPA & $.101\left(^{*}\right)$ & 0.045 & 394 \\
\hline Average monthly income & SSEWQC & $.140(* *)$ & 0.000 & 691 \\
of the family & GPA & -0.043 & 0.258 & 691 \\
\hline
\end{tabular}

** Correlation is significant at the 0.01 level (2-tailed).

* Correlation is significant at the 0.05 level (2-tailed).

The regression analysis results that show the effects of socioeconomic variables on students' SSEWQC scores of entry to their departments are shown in Table 2.

Table 2. The results of the analysis showing the effects of socioeconomic variables on students' SSEWQC scores

\begin{tabular}{|c|c|c|c|c|c|c|c|c|c|}
\hline & & $\mathrm{B}$ & Std. Error & $\beta$ & $\mathrm{t}$ & Sig. & Zero-order & Partial & Part \\
\hline \multirow{7}{*}{ 䒿 } & (Constant) & 254.5 & 5.8 & & 43.8 & .00 & & & \\
\hline & High school & 16.7 & 2.3 & .35 & 6.9 & .00 & .38 & .33 & .32 \\
\hline & Father's Education & -.9 & .9 & -.13 & -.9 & .33 & .16 & -.04 & -.04 \\
\hline & Mother's Education & -.1 & .4 & -.01 & -.2 & .81 & .14 & -.01 & -.01 \\
\hline & Father's Occupation & 3.2 & 1.5 & .10 & 2.0 & .03 & .19 & .10 & .09 \\
\hline & Income & 3.4 & 3.0 & .17 & 1.1 & .25 & .18 & .05 & .05 \\
\hline & $\mathrm{R}=.446$ & \multicolumn{3}{|c|}{ R Square $=.199$} & \multicolumn{2}{|c|}{$F_{(7.387)}=14.807$} & \multicolumn{3}{|c|}{$\mathrm{P}=.000$} \\
\hline \multirow{7}{*}{$\frac{\tilde{\sigma}}{\sum}$} & (Constant) & 251.9 & 7.6 & & 32.9 & .00 & & & \\
\hline & High school & 19.2 & 3.3 & .41 & 5.7 & .00 & .42 & .39 & .37 \\
\hline & Father's Education & -2.2 & 1.2 & -.36 & -1.7 & .07 & .10 & -.13 & -.11 \\
\hline & Mother's Education & -.5 & .5 & -.08 & -.8 & .38 & .09 & -.06 & -.05 \\
\hline & Father's Occupation & 4.9 & 2.0 & .17 & 2.4 & .01 & .26 & .17 & .15 \\
\hline & Income & 6.0 & 4.0 & .32 & 1.4 & .13 & .12 & .11 & .09 \\
\hline & $\mathrm{R}=.472$ & \multicolumn{3}{|c|}{ R Square $=.223$} & \multicolumn{2}{|c|}{$F_{(5.181)}=10.380$} & \multicolumn{3}{|c|}{$\mathrm{P}=.000$} \\
\hline \multirow{7}{*}{ 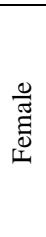 } & (Constant) & 256.1 & 8.6 & & 29.4 & .00 & & & \\
\hline & High school & 14.5 & 3.4 & .29 & 4.2 & .00 & .34 & .29 & .28 \\
\hline & Father's Education & .6 & 1.4 & .09 & .4 & .64 & .22 & .03 & .03 \\
\hline & Mother's Education & .3 & 6 & .04 & .4 & .63 & .19 & .03 & .03 \\
\hline & Father's Occupation & 1.1 & 2.2 & .03 & .5 & .61 & .13 & .03 & .03 \\
\hline & Income & .0 & 4.5 & .00 & .0 & .99 & .22 & .00 & .00 \\
\hline & $\mathrm{R}=.374$ & \multicolumn{3}{|c|}{ R Square $=.140$} & \multicolumn{2}{|c|}{$F_{(5.194)}=6.291$} & \multicolumn{3}{|c|}{$\mathrm{P}=.000$} \\
\hline
\end{tabular}

According to this table, the type of high school that students graduated from, parents' level of education and father's occupation yield a relationship at a medium level of significance with the student's SSEWQC scores $(\mathrm{R}=.446 \mathrm{R}$ Square $=.199 \mathrm{P}<.05)$. These variables account for $19.9 \%$ of the student SSEWQC scores. The relative order of importance of the predictive variables on the SSE scores based on the standardized regression coefficient are type of high school, income, father's education, father's occupation, and mother's education. When the t-test results related to the significance level of the regression coefficients are examined, it can be said that only the type of high school and father's occupation are the significant predictors on SSEWQC scores. The other variables do not have a significant effect.

When examined by gender, the type of high school, parents' level of education, and father's occupation yield a relationship at a medium level of significance with the SSEWQC scores of both male and female students (Males, $\mathrm{R}=.472 \mathrm{R}$ Square $=.223 \mathrm{P}<.05$; Females, $\mathrm{R}=.374 \mathrm{R}$ Square $=.140 \mathrm{P}<.05$ ). These variables account for $22.3 \%$ of the SSEWQC scores of the male students and $14.0 \%$ of the SSEWQC scores of the female students. When the ttest results regarding the significance of regression coefficients are studied, it can be said that the type of high school and father's occupation are significant predictors of 
male students' SSE scores. The effects of the other variables are not significant. It can be said that only the type of high school has a significant effect on the SSEWQC scores of the female students (Table 2).
The regression analysis results show that the relative effects of socioeconomic variables on students' GPAs are presented in Table 3 .

Table 3. Results of the analysis showing the effects of socioeconomic variables on student GPAs

\begin{tabular}{|c|c|c|c|c|c|c|c|c|c|}
\hline & & $\mathrm{B}$ & Std. Error & $\beta$ & $\mathrm{t}$ & Sig. & Zero-order & Partial & Part \\
\hline \multirow{7}{*}{ 㫯 } & (Constant) & 64.88 & 2.32 & & 27.89 & .000 & & & \\
\hline & High school & 2.55 & .95 & .14 & 2.67 & .008 & .13 & .140 & .138 \\
\hline & Father's Education & .36 & .38 & .14 & .94 & .347 & -.00 & .050 & .049 \\
\hline & Mother's Education & -.21 & .17 & -.08 & -1.19 & .233 & -.07 & -.063 & -.062 \\
\hline & Father's Occupation & 1.29 & .62 & .11 & 2.09 & .037 & .12 & .110 & .108 \\
\hline & Income & -1.45 & 1.21 & -.20 & -1.19 & .233 & -.03 & -.063 & -.062 \\
\hline & $\mathrm{R}=215$ & \multicolumn{3}{|c|}{ R Square $=.046$} & \multicolumn{2}{|c|}{$F_{(5.359)=} 3.497$} & \multicolumn{3}{|c|}{$\mathrm{P}=.004$} \\
\hline \multirow{7}{*}{$\frac{\frac{0}{\pi}}{\sum^{\pi}}$} & (Constant) & 65.00 & 3.40 & & 19.06 & .000 & & & \\
\hline & High school & 2.12 & 1.47 & .11 & 1.44 & .151 & .11 & .109 & .108 \\
\hline & Father's Education & .02 & .55 & .00 & .03 & .970 & -.01 & .003 & .003 \\
\hline & Mother's Education & -.15 & .25 & -.06 & -.61 & .542 & -.04 & -.047 & -.046 \\
\hline & Father's Occupation & 1.38 & .91 & .12 & 1.51 & .133 & .12 & .114 & .113 \\
\hline & Income & -.50 & 1.81 & -.07 & -.27 & .780 & -.02 & -.021 & -.021 \\
\hline & $\mathrm{R}=.185$ & \multicolumn{3}{|c|}{ R Square $=.034$} & \multicolumn{2}{|c|}{$F_{(5.172)}=1.217$} & \multicolumn{3}{|c|}{$\mathrm{P}=.303$} \\
\hline \multirow{7}{*}{ 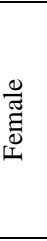 } & (Constant) & 64.61 & 3.22 & & 20.04 & .000 & & & \\
\hline & High School & 2.88 & 1.27 & .17 & 2.27 & .024 & .14 & .167 & .163 \\
\hline & Father's Education & .74 & .53 & .30 & 1.38 & .16 & .00 & .102 & .099 \\
\hline & Mother's Education & -.26 & .25 & -.10 & -1.04 & .29 & -.09 & -.077 & -.075 \\
\hline & Father's Occupation & 1.27 & .86 & .11 & 1.47 & .14 & .12 & .109 & .106 \\
\hline & Income & -2.49 & 1.67 & -.36 & -1.49 & .13 & -.04 & -.110 & -.107 \\
\hline & $\mathrm{R}=.257$ & \multicolumn{3}{|c|}{ R Square $=.066$} & \multicolumn{2}{|c|}{$F_{(5.181)}=2.570$} & \multicolumn{3}{|c|}{$\mathrm{P}=.028$} \\
\hline
\end{tabular}

According to Table 3, the type of high school, parents' level of education, and father's occupation yield a low level and significant relationship with the students' GPAs $(\mathrm{R}=.215 \mathrm{R}$ Square $=.046 \mathrm{P}<.005)$. These variables account for $4.6 \%$ of student entry scores. According to the standardized regression coefficients, within the relative order of importance of the predictive variables in the general average score is type of high school, father's level of education, and father's occupation, which are positively related, and income and mother's level of education, which are negatively related. When the t-test results regarding the significance of the regression coefficients are examined, it can be seen that only the type of high school completed is a significant predictor of GPA. The other variables do not have a significant effect.
When examined from the point of gender view, no variable has a significant effect on male students' GPAs $(\mathrm{R}=.185 \mathrm{R}$ Square $=.034 \mathrm{P}>.05)$. The type of high school completed, parents' level of education, father's occupation and income variables yield a low level of significant relationship with female students' GPAs $(\mathrm{R}=.257 \mathrm{R}$ Square $=.066 \mathrm{P}<.005)$. These variables account for $6.6 \%$ of female students' GPAs. When the t-test results are examined regarding the significance of regression coefficients, it can be said that the type of high school has a significant impact on female students' GPAs. The effect of the other variables is not significant.

The variance analysis results (Tests of BetweenSubjects Effects) that show the effects of type of high school completed on student SSEWQC scores are provided in Table 4.

Table 4. Results of analysis of variance showing the effect of type of high school completed on student SSEWQC scores and GPAs (Tests of Between-Subjects Effects)

\begin{tabular}{|c|c|c|c|c|c|c|c|c|}
\hline & & Source & Sum of Squares & $\mathrm{df}$ & Mean Square & $\mathrm{F}$ & Sig. & R Squared \\
\hline \multirow{9}{*}{ 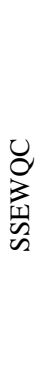 } & \multirow{3}{*}{ 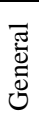 } & (Constant) & 68117.2 & 3 & 22705.7 & 37.52 & .000 & .142 \\
\hline & & Error & 410274.5 & 678 & 605.1 & & & \\
\hline & & Total & 62432729.0 & 682 & & & & \\
\hline & \multirow{3}{*}{$\frac{\frac{0}{\pi}}{\Sigma}$} & (Constant) & 36441.8 & 3 & 12147.2 & 21.618 & .000 & .146 \\
\hline & & Error & 201165.1 & 358 & 561.91 & & & \\
\hline & & Total & 32940723.0 & 362 & & & & \\
\hline & \multirow{3}{*}{ 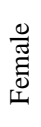 } & (Constant) & 34926.8 & 3 & 11642.2 & 17.918 & .000 & .137 \\
\hline & & Error & 205321.3 & 316 & 649.7 & & & \\
\hline & & Total & 29492006.0 & 320 & & & & \\
\hline \multirow{9}{*}{$\underset{\circlearrowleft}{\mathbb{U}}$} & \multirow{3}{*}{ 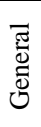 } & (Constant) & 966.1 & 3 & 322.0 & 3.564 & .014 & .017 \\
\hline & & Error & 57469.4 & 636 & 90.3 & & & \\
\hline & & Total & 3198987.2 & 640 & & & & \\
\hline & \multirow{3}{*}{$\frac{\stackrel{0}{\pi}}{\Sigma}$} & (Constant) & 334.9 & 3 & 111.6 & 1.180 & .317 & .010 \\
\hline & & Error & 31798.8 & 336 & 94.6 & & & \\
\hline & & Total & 1668586.0 & 340 & & & & \\
\hline & \multirow{3}{*}{ 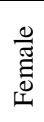 } & (Constant) & 993.8 & 3 & 331.2 & 3.926 & .009 & .038 \\
\hline & & Error & 24978.1 & 296 & 84.3 & & & \\
\hline & & Total & 1530401.2 & 300 & & & & \\
\hline
\end{tabular}


According to this table, the effect of the type of high school on SSEWQC scores are statistically significant $(\mathrm{F}(37,522)=62432729, \mathrm{P}=.000)$. When the other factors that influence student achievement are ignored, the type of high school completed accounts for $14.2 \%$ of the variability of SSEWQC scores. When examined by gender, the type of high school accounts for $14.6 \%$ of the variability of SSEWQC scores among male students, and $13.7 \%$ of the variability of the scores among female students. According to Table 4, when the other factors that influence student achievement are ignored, the type of high school completed accounts for $1.7 \%$ of the variability of GPAs. This state does not show differences based on gender. The type of high school accounts for $1 \%$ of the variability of GPAs among male students while it accounts for $3.8 \%$ of the variability of GPAs among female students.

\section{Discussion}

In the study, it is stated that the socioeconomic status of the family has a strong effect on student academic achievement. However, some research results indicate this effect to be direct while other research results indicate it to be indirect. In this study, the findings showed a positive relationship between students' SSEWQC scores and the variables that reflect the socioeconomic structure of the family. However, there is no significant relationship between the variable that reflects the family's socioeconomic status and students' general academic mean scores. One of the most important findings of this study is that there is a strong positive relationship between the type of high school that the student completed and SSEWQC scores and GPAs. It can be said that student admittance to high schools based on the results of Secondary School Selection Examination results in Turkey has led to differentiation between high schools based on academic achievement. As a result, high achieving students gather in certain types of high schools. Related to this, it can be stated that this causes a strong positive relationship between the type of high school completed and SSEWQC scores and GPAs.

When explanatory variables are examined, the type of high school that the student attended can be said to be a significant predictor of academic achievement. Familial variables are not strong predictors. Although literature makes a strong emphasis on the effects of the family's socioeconomic variables on academic attainment, the findings obtained in this study do not yield a significant relationship. School enrollment in the transition between stages of educational levels in Turkey is administered based on the results of the central examination. Student enrollment based on the results of central examinations causes the schools to differentiate based on student socioeconomic status and academic achievement. Kose stated based on the findings of the study conducted on Van province example that the social, economic and cultural differentiation becomes the fundamental factor that influences student success at the time of transition from primary to secondary level schools. He concluded that the type of primary school that the student completed is a significant predictor in high school entrance. [9] The results of this study are partially consistent with those found by Kose. Since the educational stages prior to higher education also admit students based on exams, homogeneity in student profiles in higher education has increased. The effects of the family-related variables can be said to be seen at the stages prior to higher education [9].

\section{Acknowledgements}

This study was carried out with the some data of master's dissertation called as "The effect of socioeconomic variables on the academic success of higher education students" which was prepared by Gökhan POLAT under the consultancy of Ekber TOMUL.

\section{References}

[1] Butlin, G., "Determinants of post-secondary participation", Education Quarterly Review, 5 (3), 9-35. 1999.

[2] Finnie, R., Lascelles, E., Sweetman, A., Who goes? The direct and indirect effects of family background on access to post-secondary education. Statistics Canada Analytical Studies - Research Paper Series, 11F0019, No: 237. 2005.

[3] Ewenıy, G., The impact of family structure on university students' academic performance. 2005. Available: http://64.233.183.104/search?q=cache:D7sSsLcw26wJ:www.ijeun ilorin.net/ Accessed December, 14, 2007.

[4] OECD. Learning for tomorrow's world first results from PISA 2003. (No.9264007245). Paris: OECD. (2005)

[5] Caldas, S.J. \& Bankston, C., "Effect of school population socioeconomic status on individual academic achievement”, The Journal of Educational Research, 90(5), 269-277. 2004.

[6] Chiu, M.M., "Families, economies, cultures, and science achievement in 41 countries: country, school, and student level analyses”, Journal of Family Psychology, 21(3), 510-519. 2007.

[7] Rothman, S., "The changing influence of socioeconomic status on student achievement: recent evidence from Australia”. Paper presented at American Educational Research Association, 21-25 April, Chicago, 2003. Accessed 11 June 2007. 2003.

[8] Wößmann, L., How equal are educational opportunities? Family background and student achievement in Europe and in US, Available: www.CESifo.de. 2004. Accessed 14 September 2007.

[9] Köse, R., "Aile sosyo-ekonomik ve demografik özellikleri ile okul ve özel dershanenin liselere giriş sınavına katılan öğrencilerin akademik başarıları üzerindeki etkileri [Effects of School and Private Courses on the academic achievement of students taking the high school entrance exams from the aspect of socioeconomic and demographic characteristics of the family]". Eğitim Bilim Toplum, 5(17), 46-77. 2007.

[10] Ichado, S. M., "Impact of broken home on academic performance of secondary school students in English Language”, Journal of Research in Counseling Psychology, 4(1), 84-87. 1998.

[11] Eskicumalı, A., Eğitim, sosyal sınıf, ekonomi, kültür ve irk ilişkileri [Relationships between education, school class, economy, culture and race]. Yayınlanmamış Araştırma, Selçuk Üniversitesi, Konya. 2000.

[12] Croll, P., "Families, social capital, and educational outcomes" British Journal of Educational Studies, 52(4), 390- 416. 2004.

[13] Kean, K., Tsai, W-D., "Parenting practices and children's education outcomes", Economics of Education Review, 24(1), 2943. 2005.

[14] McMillan, J., Western, J. "Measurement of the socio-economic status of Australian higher education students" Higher Education, 39, 223-248. 2000.

[15] Rumberger, R. W., Palardy, G. J., "Does segregation still matter? The impact of student composition on academic achievement in high school” Teachers College Record, 107(9), 1999-2045. 2005.

[16] Ewijk, R., The effect of ethnicity and SES in the class on achievement: a meta-analysis. Paper ICO-toogdag 2006 SCOKohnstamm Institute, Faculty of Social and Behavioral Sciences, University of Amsterdam, The Netherlands. 2006. 
[17] Tomul, E., Savasci, H.S. "Socioeconomic determinants of academic achievement”, Educational Assessment, Evaluation and Accountability. 24 (3), 175-187. (2012).

[18] Konan, P., Chatard, A., Selimbegović, L., Mugny, G., "Cultural diversity in the classroom and its effects on academic performance: A cross-national perspective”, Social Psychology, 41(4), 230-237. 2010.

[19] Gümüş, S., Gümüş, E., “Achieving Gender Parity in Primary School Education in Turkey via the Campaign called "Haydi Kizlar Okula" (Girls, Let's Go to School)" Education and Science, 38(167), 17-26. 2013.

[20] Heyneman, S., W. Loxley, “The effect of primary school quality on academic achievement across twenty-nine high and low income countries”, American Journal of Sociology, 88,1162-1194. 1989.

[21] Currie, J., Moretti, E., “Mother's education and the intergenerational transmission of human capital, evidence from college openings and longitudinal data” Quarterly Journal of Economics, 118, 1495-1532. 2003.

[22] Elmacıoğlu, T., Başarıda aile faktörü [The family factor in success]. Hayat Yayıncılık, İstanbul, 2003.

[23] De Broueker, P., Underwood, K., "Intergenerational education mobility: a international comparison with a focus on postsecondary education” Education Quearterly Review, 5(2), 3045. 1998.

[24] Harmon, C., Walker, I. The returns to the quantity and quality of education: evidence for men in England and Wales. Economica, 67(265), 19-35. 2000.
[25] Chevalier, A., Lanot, G., "The Relative effect of family characteristics and financial situation on educational achievement" Education Economics, 10(2), 166-180. 2002.

[26] Brunello, G. \& Checchi, D., "School quality and family background in Italy”. Economics of Education Review, 24(5), 563-577. 2005.

[27] Blanden, G., \& Gregg, P., Family income and educational attainment: a review of approaches and evidence for Britain. CMPO Working Paper, 04/110. 2004.

[28] Liu, J-T., Chou, S-Y., Liu, J-L. “Asymmetries in progression in higher education in Taiwan: parental education and income effects” Economics of Education Review, 25(6), 647-658. 2006.

[29] Crosnoe, R., Mistry, R. S., Elder, G. H. "Economic disadvantage, family dynamics, and adolescent enrollment in higher education", Journal of Marriage and Family, 64, 690-702. 2002.

[30] Smits, J., Parents' investment in children's education in Morocco, Algeria, Tunisia, Egypt and Syria. Available: http:/www.ru.nl/nice. Accessed December, 11, 2007. 2007.

[31] Student Selection and Placement Center (SSPC). Available: http://www.osym.gov.tr/BelgeGoster.aspx?F6E10F8892433CFF1 A9547B61DAFFE2A185C4781D0FBC79E. Accessed February 20, 2008.

[32] Polat, G., The effect of socio-economic variables on the academic success of higher education students. Master's thesis, Social Sciences Institute of Mehmet Akif Ersoy University. 2008. 